\title{
The Physical Environment in the City of Light
}

Harold A. Widdison, Ph.D.

Northern Arizona University

Craig R. Lundahl, Ph.D.

Western New Mexico University

ABSTRACT: The article describes the physical environment found in the other world or the City of Light, based on published accounts of near-death experiences (NDEs). The City of Light appears to be a world of preternatural beauty that cannot be described adequately. NDE accounts provide descriptions of the landscape, animal life, plant life, and architecture found in the other world.

Since the inception almost twenty years ago of the modern field of near-death studies, only Craig Lundahl (1981-82) has utilized information from near-death experiences (NDEs) to describe in some detail the physical dimension of the perceived other world, or "cities of light," as it has been labelled by Raymond Moody (1977). Lundahl (1981-82) briefly described buildings, landscape, and vegetation in the other world of the NDE. Other researchers, such as Ray Canning (Lundahl,

Harold A. Widdison, Ph.D., is Professor of Sociology at Northern Arizona University. Craig R. Lundahl, Ph.D., is Professor of Sociology and Business Administration and Chair of the Department of Social Sciences at Western New Mexico University. The authors thank Jay G. Burrup for providing a section of the Diary of George Henry Carver. This research was supported in part by a sabbatical leave granted to Dr. Lundahl by the Sabbatical Leave Committee of Western New Mexico University. 
1981-82), Karlis Osis and Erlendur Haraldsson (1977), Kenneth Ring (1980), and Michael Sabom and Sarah Kreutziger (Sabom, 1982) have documented NDE accounts that shed some light on the physical environment in the City of Light.

Since Lundahl's work over a decade ago, a considerable amount of new material on NDEs has been collected and published from old diaries and journals and from contemporary sources, which has provided us with additional information on the physical environment of the City of Light. The purpose of this article is to look at past as well as newly published NDE accounts to enlarge our understanding of the physical environment in the other world, including the landscape, animal life, plant life, and architecture of the City of Light.

\section{The Physical Environment in the City of Light}

The City of Light is another realm that has been described by NDErs as a world of preternatural and ethereal beauty, with colors said to be unforgettable, heavenly landscapes in incredible detail, and exquisite music unlike anything ever experienced on earth. NDErs also have described the most beautiful buildings of the finest workmanship, vegetation and flowers that are beautiful beyond description with every color in the rainbow, and animals. The City of Light is described as always springtime, with a shining sun, clouds, fog, skies, and stars (Crowther, 1967; Nelson, 1988, 1989; Sabom, 1982).

One NDEr described the City of Light in terms characteristic of the way many NDErs describe the other world: "I was transported to the most beautiful place I have ever seen, so beautiful I cannot adequately describe it" (Nelson, 1989, p. 83). A child NDEr said simply "I have been to such a beautiful place," and later asked his father to let him go back, repeating "I have been to such a beautiful place" (Heinerman, 1978. p. 118).

After presenting near-death accounts of the other world, Kenneth Ring concluded:

A casual perusal of all the accounts presented in this section-even the very brief ones-will be sufficient to reveal that each of them, without exception, uses the adjective beautiful to describe the sensed features of the "surroundings" where these respondents found them. selves. If, for the time being, I may take the liberty of speaking about this realm as a "world" of its own, then, plainly and without equivocation, it is experienced as a surpassingly beautiful one. Reading these 
accounts, it is understandable why a person entering such a world would be reluctant, even unwilling, to return to the world of ordinary experience. (1980, p. 66)

\section{The Landscape of the City of Light}

The landscape of the City of Light is much like that of the earth, but much more beautiful (Nelson, 1990). It contains mountains (Eadie and Taylor, 1992; Gibson, 1992; Ring and Franklin, 1981-82), small and large hills and rocks (Nelson, 1990; Sabom, 1982), and beautiful, crystal-like valleys (Eadie and Taylor, 1992; Ring, 1980, 1982). There are large empty fields with high golden grass that is very soft, outstandingly beautiful, and very bright (Ring, 1980), and beautiful meadows with beautiful grass (Morse and Perry, 1992), and the most beautiful and greenest pastures (Sabom, 1982). In many of these areas are paths (Ring, 1982), meadow lanes (Ring, 1980), and trails through the great forest of trees (Crowther, 1967).

In the landscape nearby the City of Light are found wonderful and large lakes with beautiful, clear water, and light blue lakes (Crowther, 1967; Gallup and Proctor, 1982; Ring, 1980), rivers (Eadie and Taylor, 1992; Gibson, 1992), clear streams (Gallup and Proctor, 1982; Sabom, 1982), and trickling brooks (Nelson, 1989). The most beautiful parks ever seen are located both in the City of Light (Nelson, 1989) and outside the city (Carver, 1881).

\section{Animal Life in the City of Light}

Although NDErs rarely mention animal life in the City of Light, a few near-death accounts refer to birds, cattle, sheep, and horses. One NDEr saw all kinds of animals outside the beautiful cities in the other world (Carver, 1881). Another experiencer said "there were animals: birds, butterflies, and small furry creatures, one resembling a fawn" (Gibson, 1992, p. 145). One NDEr stated that he observed green grass scattered with delicate purple flowers, and exquisite little birds singing (Sorensen and Willmore, 1988). There were singing birds also in one of Ring's near-death accounts (Ring, 1980). Finally, Sabom (1982) reported one NDE account in which the NDEr saw cattle and sheep, and a separate one in which the NDEr saw horses; and an NDEr described by Melvin Morse and Paul Perry (1992) also saw horses. 
The importance of these observations of animal life in the other world is the implication they have for the existence of animal spirits as well as human spirits in the afterlife.

\section{Plant Life in the City of Light}

There is no lack of reports by NDErs on the plant life found in the City of Light. It appears from these reports that all forms of plant life are found there, including grass, lawns, vines, flowers, gardens, shrubs, and trees. One NDEr went to a large empty field that had high, golden grass that was very soft and very bright; this swaying grass was so outstandingly beautiful that the NDEr said she would never forget it (Ring, 1980). Beautiful crisp, cool, and brilliant green grass scattered with delicate purple flowers are found there also (Eadie and Taylor, 1992; Sabom, 1982; Sorensen and Willmore, 1988).

One NDEr found a trail through the woods that was almost obscured by grass (Crowther, 1967). Another NDEr found her surroundings in the City of Light were beautiful, like a garden, with flowers, a lawn, and trees, and reminded her of a park by a river that she visited as a child for family reunions (Nelson, 1989).

Among the rich foliage in the City of Light are many green plants (Eadie and Taylor, 1992; Morse and Perry, 1992; Nelson, 1990) and vines. One NDEr visited a place that was "divided into compartments by walls, from which appeared to grow out vines and flowers, displaying an endless variety of colors" (Crowther, 1967, p. 75).

The flowers in the City of Light are so beautiful they almost defy description. One NDEr said he saw flowers of numerous kinds, including some plants with from 50 to 100 different colored flowers growing upon one stalk (Crowther, 1967). Another NDEr said he saw "the most beautiful flowers. Nobody on this earth ever saw the beautiful flowers that I saw there. ... I don't believe there is a color on this earth that wasn't included in that color situation that I saw" (Ring, 1982, p. 143). NDErs have reported sparkling flowers of every color in the rainbow, and fields and landscapes filled with flowers (Eadie and Taylor, 1992; Gallup and Proctor, 1982; Gibson, 1992; Morse and Perry, 1992). They have described purple flowers, daisies, and beautiful flowers of all kinds (Ring and Franklin, 1981-82; Sorensen and Willmore, 1988), tall flowers (Green and Friedman, 1983) and large flowers that look like big, tall dahlias (Moody and Perry, 1988). Some NDErs have reported smelling these flowers as well (Nelson, 1989). 
Further examination of near-death accounts of the plant life in the City of Light finds gardens mentioned frequently. The best gardens on the earth do not even compare to the gardens in the City of Light (Crowther, 1967). One NDEr said she did not have the words to describe the beauty of the garden she entered there: "It was more beautiful that anything I had ever seen on earth, including the Koukenhoff Garden in Holland at tulip time" (Nelson, 1988, p. 123). This same feeling was expressed by another experiencer (Morse and Perry, 1992). Another NDEr woke up in a garden filled with large flowers: "It was warm and light in this garden and it was beautiful" (Moody and Perry, 1988 , p. 59). Betty Eadie entered into a garden filled with trees, flowers, and plants with intense colors (Eadie and Taylor, 1992). Other experiencers have described a garden similar to a wooded area with tropical plants and gardens with beautiful sidewalks, benches, and patios (Gibson, 1992).

Many trees and shrubs are found in the City of Light. NDErs often mention trees and shrubs in the other world, describing them as beautiful trees, groups of trees, and great forests of beautiful trees (Crowther, 1967; Eadie and Taylor, 1992; Gallup and Proctor, 1982; Gibson, 1992; Morse and Perry, 1992; Nelson, 1988, 1989). Some of these forests are pine forests (Nelson, 1990), and some are filled with trees in full bloom (Nelson, 1989). One NDErs observed that the trees she saw "were all in the shadows of gold. There was no green, no blue" (Sabom, 1982, p. 46).

At least one NDEr observed that there are no weeds in the City of Light (Gibson, 1992). These descriptions of the plant life in the City of Light portray a beauty in plant life that is difficult even to imagine.

\section{Architecture in the City of Light}

Architectural features in the City of Light described by NDErs include an entry gate, the city with golden pathways and bridges, a variety of buildings, homes of various sizes, and beautiful rooms.

There appears to be a gate at the entrance to the City of Light, described by one NDEr as the "golden gates of heaven" (Sabom, 1982, p. 46), by another as "a gold ornamental gate, wrought-iron in appearance, with a highly polished color" (Sabom, 1982, p. 46), and by a third as a "beautiful white gate" (Green and Freidman, 1983, p. 90).

Beyond the gate is a city, the City of Light (Heinerman, 1978; Sorensen and Willmore, 1988). We use the term City of Light here to 
represent cities in general in the other world, since that realm actually contains a number of fine and beautiful cities (Carver, 1881). The city has been described as a gorgeous and beautiful kingdom that is wholly white (Green and Friedman, 1983), and as a place with beautiful buildings and golden pathways (Nelson, 1990). It has beautiful streets throughout that are paved with beautiful silk carpet (Carver, 1881) and includes bridges (Sabom, 1982).

The buildings in the City of Light are said to be very beautiful, have the finest workmanship, and are better constructed than those on earth. One NDEr spoke "of the buildings he saw there, remarking that the Lord gave Solomon wisdom and poured gold and silver into his hands that he might display his skill and ability, and said that the temple erected by Solomon was much inferior to the most ordinary buildings he saw in the spirit world" (Crowther, 1967, p. 77). Another experiencer entering a large building said, "I was impressed with its details and exquisite beauty. Buildings are perfect there; every line and angle and detail is created to perfectly compliment [sic] the entire structure" (Eadie and Taylor, 1992, p. 108). The buildings include huge amphitheaters (Nelson, 1990), a beautiful palace that an NDEr described as the House of David (Gallup and Proctor, 1982), marble mausoleum-like structures filled with light (Ring, 1980), large halls (Crowther, 1967), and libraries or educational buildings (Gibson, 1992).

George Ritchie described enormous buildings in a beautiful sunny park where there was a relationship between the various structures, a pattern to the way things were arranged, like a well-planned university. He described entering one of the buildings and moving down a high-ceilinged corridor lined with tall doorways. The atmosphere of the place was that of a tremendous study center with wide halls and curving stairways. Through open doorways he glimpsed enormous rooms filled with complex equipment, intricate charts and diagrams, controls, and elaborate consoles. He described visiting other buildings, including a studio where very complex music was being composed and performed; a vast library filled with documents on parchment, clay, leather, metal, and other materials; and a space observatory. At the apex of Ritchie's NDE, he reported seeing a city made of light (Ritchie and Sherrill, 1978).

Among the buildings in the City of Light are homes. One NDEr reported her deceased brother told her that their grandparents had a beautiful home and that they were preparing a beautiful home for his mother and her family (Crowther, 1967). Another visitor to the City of Light said she saw many beautiful homes, some spacious and others small; some of the homes were barely larger than a small kitchen or 
large bathroom. When she asked her deceased brother, who was accompanying her through the City of Light, why anyone would want to live in a house so small, he said, "That was all the good works they sent up" (Nelson, 1990, p. 99), implying that the size of house a person gets in the City of Light is determined by the quantity and quality of the good deeds they performed on earth.

The rooms of these various structures are beautiful, as evidenced by the comments of NDErs who have visited there. For example, one NDEr described a large, white room he was in as beautiful, with an amber gold floor that reflected every image like a mirror. The walls were trimmed with gold, and at one end of the room stood two large doors, also trimmed in gold (Nelson, 1989). Another NDEr said that human words were not adequate to describe the beauty of the room she entered while in the other world: "There was a lot of light, a brightness that went beyond just white-kind of a many-colored iridescence. We don't have the words in our language to describe the beauty, not only of the room, but the people too" (Nelson, 1988, p. 68). Ricky Davis, a 12 year-old boy, told his parents he had "already visited two rooms of the temple on the other side, and if we had seen what he had seen, we would all want to go with him" (Davis, 1982, p. 70).

Many near-death accounts suggest that the rooms in various buildings and homes are furnished. Betty Eadie described the rooms as beautiful, exquisitely built and appointed (Eadie and Taylor, 1992). Another NDEr came to a very large, beautiful building that was yet unfinished, with a porch around it; inside was a most beautiful and large bedroom, with beautiful workmanship. The floors of the bedroom were as of gold and lovely beds were in the room (Crowther, 1967).

\section{Conclusion}

This study of the physical environment in the other world has drawn upon published NDE reports by near-death researchers over nearly twenty years. The information has provided a fairly detailed description of the landscape, animal life, plant life, and architecture of the City of Light. Gorgeous landscapes are reported, along with animal life and exquisite and eye-filling vegetation. The buildings and rooms display superior workmanship and construction and they are endowed with beauty and elegance. The one word NDErs repeatedly use to describe the physical environment in the other world is "beautiful," and quite often they comment that human words are inadequate to describe the beauty of the City of Light. 


\section{References}

Carver, G. H. (1881). Diary of George Henry Carver. Unpublished manuscript in the possession of Jay G. Burrup.

Crowther, D. S. (1967). Life everlasting. Salt Lake City, UT: Bookcraft.

Davis, J. (1982). Hurry home, Dad: Today I'm going to die. Salt Lake City, UT: Hawker.

Eadie, B. J., and Taylor, C. (1992). Embraced by the light. Placerville, CA: Gold Leaf.

Gallup, G., Jr., and Proctor, W. (1982). Adventures in immortality: A look beyond the threshold of death. New York, NY: McGraw-Hill.

Gibson, A.S. (1992). Glimpses of eternity: New near-death experiences examined. Bountiful, UT: Horizon.

Green, T. J., and Friedman, P. (1983). Near-death experiences in a Southern California population. Anabiosis: The Journal of Near-Death Studies, 3, 77-95.

Heinerman, J. (1978). Spirit world manifestations. Salt Lake City, UT: Magazine Printing and Publishing.

Lundahl, C. R. (1981-82). The perceived other world in Mormon near-death experiences: A social and physical description. Omega, 12, 319-327.

Moody, R. A., Jr. (1977). Reflections on life after life St. Simon's Island, GA: Mockingbird.

Moody, R. A., Jr., and Perry, P. (1988). The light beyond. New York, NY: Bantam.

Morse, M. L., and Perry, P. (1992). Transformed by the light: The powerful effect of neardeath experiences on people's lives. New York, NY: Villard.

Nelson, L. (1988). Beyond the veil. Volume one. Orem, UT: Cedar Fort.

Nelson, L. (1989). Beyond the veil. Volume two. Orem, UT: Cedar Fort.

Nelson, L. (1990). Beyond the veil. Volume three. Orem, UT: Cedar Fort.

Osis, K., and Haraldsson, E. (1977). At the hour of death. New York, NY: Avon.

Ring, K. (1980). Life at death: A scientific investigation of the near-death experience. New York, NY: Coward, McCann and Geoghegan.

Ring, K. (1982). Frequency and stages of the prototypical near-death experience. In Lundahl, C. R. (Ed.), A collection of near-death research readings (pp. 110-147). Chicago, IL: Nelson-Hall.

Ring, K., and Franklin, S. (1981-82). Do suicide survivors report near-death experiences? Omega, 12, 191-208.

Ritchie, G., and Sherrill, E. (1978). Return from tomorrow. Waco, TX: Chosen Books.

Sabom, M. B. (1982). Recollections of death: A medical investigation. New York, NY: Harper and Row.

Sorensen, M. R., and Willmore, D. R. (1988). The journey beyond life. Volume one. Orem, UT: Family Affair Books. 